\title{
Laboratory studies of rice bran as a carbon source to stimulate indigenous microorganisms in oil reservoirs
}

\author{
Chun-Mao Chen ${ }^{1,2} \cdot$ Jin-Ling Wang ${ }^{1} \cdot$ Jung Bong Kim ${ }^{3} \cdot$ Qing-Hong Wang ${ }^{1}$. \\ Jing Wang ${ }^{1} \cdot$ Brandon A. Yoza ${ }^{4}$ Qing X. $\mathbf{L i}^{2}$
}

Received: 2 September 2015/Published online: 2 July 2016

(c) The Author(s) 2016. This article is published with open access at Springerlink.com

\begin{abstract}
There is a great interest in developing cost-efficient nutrients to stimulate microorganisms in indigenous microbial enhanced oil recovery (IMEOR) processes. In the present study, the potential of rice bran as a carbon source for promoting IMEOR was investigated on a laboratory scale. The co-applications of rice bran, $\mathrm{K}_{2} \mathrm{HPO}_{4}$ and urea under optimized bio-stimulation conditions significantly increased the production of gases, acids and emulsifiers. The structure and diversity of microbial community greatly changed during the IMEOR process, in which Clostridium sp., Acidobacteria sp., Bacillus sp., and Pseudomonas sp. were dominant. Pressurization, acidification and emulsification due to microbial activities and interactions markedly improved the IMEOR processes. This study indicated that rice bran is a potential carbon source for IMEOR.
\end{abstract}

Chun-Mao Chen

chunmaochan@163.com

Qing X. Li

qingl@ hawaii.edu

1 State Key Laboratory of Heavy Oil Processing, China University of Petroleum, Beijing 102249, China

2 Department of Molecular Biosciences and Bioengineering, University of Hawaii at Manoa, Honolulu, HI 96822, USA

3 Department of Agro-Food Resources, National Institute of Agricultural Sciences, Rural Development Administration, Jeonju 55365, Republic of Korea

4 Hawaii Natural Energy Institute, University of Hawaii at Manoa, Honolulu, HI 96822, USA

Edited by Xiu-Qin Zhu
Keywords Rice bran · Bio-stimulation · Petroleum · Microbial diversity $\cdot$ Indigenous microbial enhanced oil recovery

\section{Introduction}

Increasing demand for crude oil is promoting the development of oil extraction technologies. Among these, microbial enhanced oil recovery (MEOR) is a promising tertiary oil recovery technology for depleted oil fields (Brown 2010; Sen 2008). Indigenous microorganisms, which naturally inhabit oil reservoirs, show a greater metabolic activity than exogenous ones due to their long-term adaptation (CastorenCortés et al. 2012; Lazar et al. 2007). Therefore, indigenous microorganisms activated MEOR (IMEOR) has greater efficiency than using exogenous ones (Yao et al. 2012; Zhang et al. 2012). Stimulation, growth and propagation of beneficial microorganisms that can contribute to producing effective metabolites are critical to the application of IMEOR (Zhang et al. 2010). The metabolites mainly include gases, acids and emulsifiers (Gao and Zerki 2011). Gases can pressurize the oil reservoir and reduce the viscosity of crude oil (Kobayashi et al. 2012; Spirov et al. 2014). Acids may increase carbonate rock porosity and permeability, thereby promote the exudation of remained oil (Sen 2008). Emulsifiers can emulsify crude oil, lower its viscosity and improve its fluidity (Banat et al. 2010; Dastgheib et al. 2008; Kitamoto et al. 2009; Sarafzadeh et al. 2013; She et al. 2011). The multiple effects of various metabolites improve oil flooding and thus enhance crude oil recovery.

Efficient production of beneficial metabolites is needed during an IMEOR process. However, nutrients in an oil reservoir are often insufficient and unbalanced, thus cannot provide adequate bio-stimulation (Wang et al. 2012). The 
injection of nutrients can optimize bio-stimulation conditions in an oil reservoir (Gao et al. 2013). The injected nutrients should stimulate beneficial microorganisms but restrain harmful ones, while they should not cause formation damage or contamination (da Silva et al. 2014). More importantly, the nutrients should be economical. Of these nutrients, carbon sources have an overwhelming influence on bio-stimulation effects and application costs. Carbohydrates such as molasses, corn syrup, malt dextrin sucrose and starch have been explored for use in IMEOR in past decades (Bao et al. 2009; Joshi et al. 2008). As market prices of carbohydrates are rising, finding an economical carbon source has been a significant motivation. Rice bran, as an abundant agricultural by-product, has been used to prepare culture media for enzymatic solid-state fermentations ( $\mathrm{Ng}$ et al. 2010; Noike and Mizuno 2000; Tanaka et al. 2006). However, it has not been investigated as a biosimulator to promote IMEOR.

The objective of this study was to investigate the industrial potential of rice bran to promote IMEOR. Additionally, the bio-stimulation mechanism of rice bran can be acquired by the microbial diversity analysis during an IMEOR process. The results could be hopefully beneficial to reduce IMEOR cost and would generate value from agricultural by-products.

\section{Materials and methods}

\subsection{Materials}

The formation water and crude oil were both sampled from the Qixi block of Karamay oil field, which is located in Xinjiang Uygur Autonomous Region, Northwest China. Water flooding has been implemented by recycling production water for 40 years. The sampling and storage methods were as previously described (Tang et al. 2012). The initial temperature, $\mathrm{pH}$ and salinity of the formation water were $33.5^{\circ} \mathrm{C}, 7.85$ and $5054 \mathrm{mg} / \mathrm{L}$, respectively. The kinematic viscosity $\left(50{ }^{\circ} \mathrm{C}\right)$ and density $\left(20^{\circ} \mathrm{C}\right)$ of the crude oil were $62.33 \mathrm{~mm}^{2} / \mathrm{s}$ and $0.912 \mathrm{~g} / \mathrm{cm}^{3}$, respectively.

The nutrients that were used to stimulate microorganisms in an IMEOR process commonly included carbon, nitrogen and phosphorus sources. The carbon nutrients were selected from several agricultural by-products including rice bran (reducing sugar at $390 \mathrm{mg} / \mathrm{g}$ and total nitrogen at $2.21 \mathrm{mg} / \mathrm{g}$ ), wheat bran (reducing sugar at $280 \mathrm{mg} / \mathrm{g}$ and total nitrogen at $0.45 \mathrm{mg} / \mathrm{L})$, corn residue, rice husk, glycerol residue and molasses. Rice bran and wheat bran were pulverized to 100 mesh particles prior to the experiment. The nitrogen sources were urea, $\mathrm{NH}_{4} \mathrm{Cl}$, $\mathrm{KNO}_{3}$ and $\mathrm{NaNO}_{3}$. The phosphorus sources were $\mathrm{K}_{2} \mathrm{HPO}_{4}$, $\mathrm{NH}_{4} \mathrm{H}_{2} \mathrm{PO}_{4}, \quad \mathrm{NaH}_{2} \mathrm{PO}_{4}, \quad \mathrm{KH}_{2} \mathrm{PO}_{4}, \quad\left(\mathrm{NH}_{4}\right)_{2} \mathrm{HPO}_{4} \quad$ and
$\mathrm{Na}_{2} \mathrm{HPO}_{4}$. The agricultural by-products were purchased from a local market. All nitrogen and phosphorus sources were from Beijing Chemical Reagents Co., China.

\subsection{Optimization experiments of bio-stimulation conditions}

Preferred nutrients and their basic concentrations were selected by single factor optimization (SFO) experiments. Concentrations of preferred nutrients were further optimized by orthogonal design experiments (Chen et al. 2010). The optimized bio-stimulation conditions were quantified with response surface methodology (RSM) experiments based on a Box-Behnken design (Chen et al. 2007). Response surface regression analysis and analysis of variance (ANOVA) were performed by Minitab software (Version 16, Minitab Inc, State College, PA, USA). The experiments were carried out with $250 \mathrm{~mL}$ SIBATA fermentation bottles. Various nutrients at different concentrations and $50 \mathrm{~mL}$ distilled water were introduced into the bottles, followed by $\mathrm{pH}$ adjustment to 7.85. After sterilization at $115^{\circ} \mathrm{C}$ for $30 \mathrm{~min}$, the bottles were inoculated with $50 \mathrm{~mL}$ of formation water and $5 \mathrm{~g}$ of crude oil, and then incubated at $33.5{ }^{\circ} \mathrm{C}$ and $110 \mathrm{rpm}$ for 7 days. Gas production and surface tension were indicators of biostimulation effects. All experiments were done in triplicate.

\subsection{Laboratory-scale experiments of IMEOR}

The potential of rice bran was investigated in $250 \mathrm{~mL}$ SIBATA fermentation bottles to simulate an IMEOR process. The initial broth contained $50 \mathrm{~mL}$ of formation water, $5 \mathrm{~g}$ of crude oil and optimized nutrient components, and was diluted to a final volume of $100 \mathrm{~mL}$ with distilled water. Sterilization followed the protocols described in the above-mentioned optimization experiments, as well as the incubation conditions with an extended 10 day incubation period. An aliquot of $0.05 \mathrm{~mL}$ Resazurin solution $(0.1 \mathrm{wt} \%)$ was added to each bottle as a visual anaerobic status indicator. Simulated IMEOR experiments were carried out in triplicate.

The bio-stimulation effects were measured during experiments. The produced gases which mainly reflected the re-pressurization of an oil reservoir were collected in a Devex gas collecting bag $(0.3 \mathrm{~L})$, and the gas volume was recorded by a graduated syringe. The gas composition was analyzed on a HP 6890 gas chromatograph (GC) (Agilent, Wilmington, DE, USA) equipped with a TCD detector $\left(80{ }^{\circ} \mathrm{C}\right)$ and a Porapak Q packing column $\left(60^{\circ} \mathrm{C}\right)$. Helium was used as carrier gas. The $\mathrm{pH}$ values which indicated the production of acids were measured on a PHSJ-4 meter (Leici, Shanghai, China). Two $\mathrm{mL}$ of broth was extracted by a graduated syringe and injected to a $5-\mathrm{mL}$ centrifuge tube for 
pH measurement. Bacterial numbers were counted by a cell counting method (Zhou and Wang 2004). Surface tension and emulsification degree both characterized the production of emulsifiers such as biosurfactants, biopolymer, acids and solvents. Surface tension was measured with a JK99B tensiometer (Powereach, Shanghai, China), and emulsification degree was obtained with the emulsification index (\%, EI 24) method (Reddy et al. 2010).

\subsection{Analysis of microbial diversity}

Describing the relationship between the microbial community structures and their functions will contribute to understanding of bio-stimulation mechanisms (Fuhrman 2009). Polymerase chain reaction-denaturing gradient gel electrophoresis (PCR-DGGE) has been widely used in microbial community analysis (Wang et al. 2008a, b). Aliquots $(2 \mathrm{~mL})$ of fermentation broth were collected from the bottles. After centrifugation at 10,000 rpm for $5 \mathrm{~min}$, the total DNA was extracted with a genomic DNA extraction kit (TaKaRa, Dalian, China) according to the supplier's instructions. PCR-DGGE was performed as previously described in literature ( $\mathrm{Ji}$ et al. 2009). DGGE profiles, including the presence, intensity and abundance of the bands, were analyzed with Quantity One software (Version 4.4, Bio-Rad, Hercules, CA, USA). Microbial diversity was calculated by Shannon-Wiener's indexes $(H)$ (Andreoni et al. 2004). Dominant bands were excised from the gels and re-amplified, and the fragments were recovered and cloned again. The positive clones were selected and sequenced (Sangon, Shanghai, China). Typical sequences were analyzed using the NCBI BLAST database to identify the closest relatives. A phylogenetic tree was constructed with MEGA software (Version 5.0).

\section{Results}

\subsection{Optimized bio-stimulation conditions}

Rice bran, $\mathrm{K}_{2} \mathrm{HPO}_{4}$ and urea were selected as preferred carbon, phosphorus and nitrogen sources, respectively (Fig. 1). An optimal bio-stimulation condition was preliminarily estimated to be $2.0 \mathrm{~g} / 100 \mathrm{~mL}$ of rice bran, $0.05 \mathrm{~g} /$ $100 \mathrm{~mL}$ of $\mathrm{K}_{2} \mathrm{HPO}_{4}$ and $0.05 \mathrm{~g} / 100 \mathrm{~mL}$ of urea under $\mathrm{SFO}$ experiments (Fig. 2). The concentrations of rice bran, $\mathrm{K}_{2} \mathrm{HPO}_{4}$ and urea were further optimized to be 3.0, 0.07 and $0.07 \mathrm{~g} / 100 \mathrm{~mL}$, respectively, under $3^{3}$ orthogonal design experiments (Table 1). According to the Box-Behnken experiments (Table 2) and subsequent response surface regression analysis (Fig. 3), the optimal bio-stimulation conditions were estimated as $3.36 \mathrm{~g} / 100 \mathrm{~mL}$ of rice bran, $0.075 \mathrm{~g} / 100 \mathrm{~mL}$ of $\mathrm{K}_{2} \mathrm{HPO}_{4}$ and $0.076 \mathrm{~g} / 100 \mathrm{~mL}$ of urea.
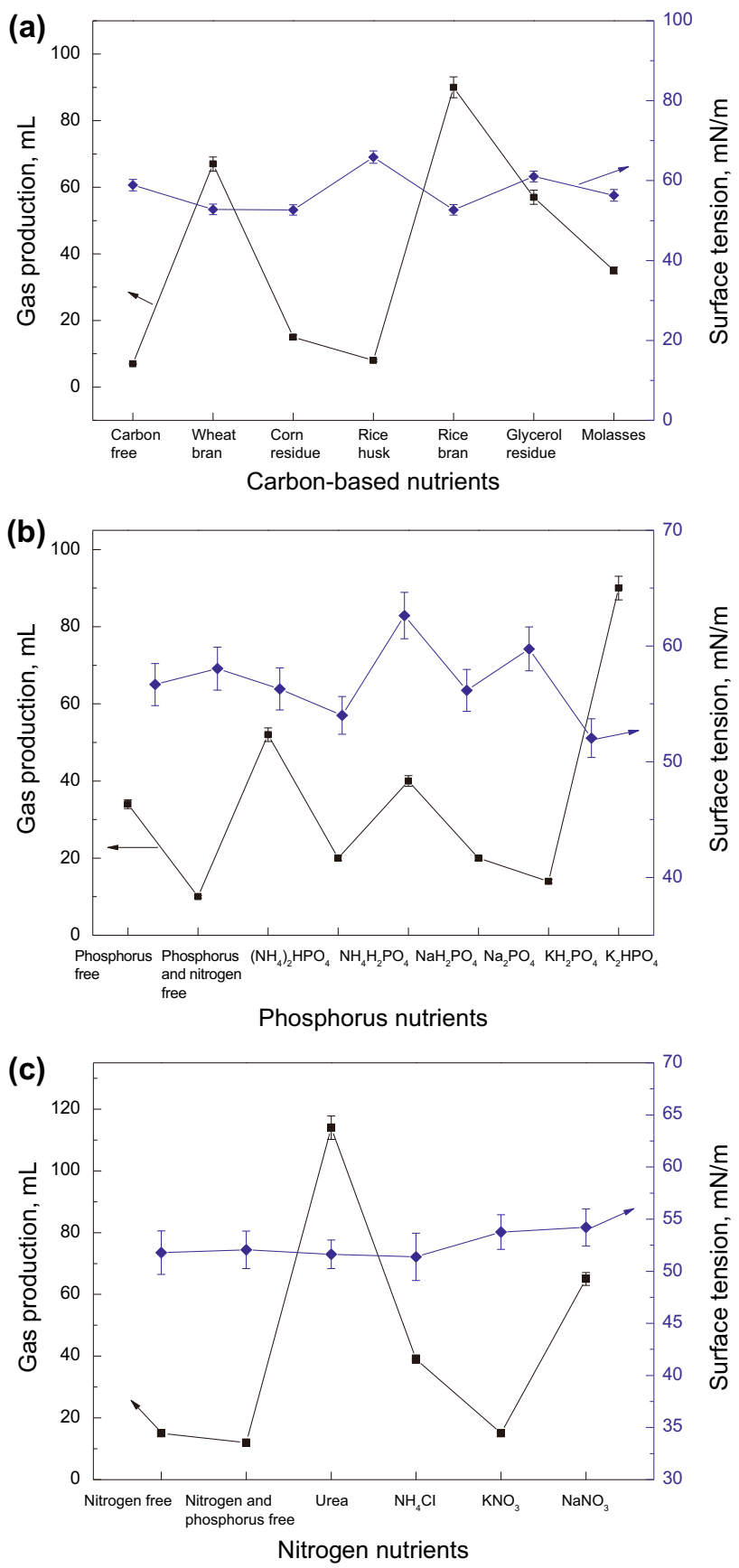

Fig. 1 Screening of preferred carbon nutrient $(1.0 \mathrm{~g} / 100 \mathrm{~mL}$ carbon sources, $0.1 \mathrm{~g} / 100 \mathrm{~mL}$ urea and $\left.0.1 \mathrm{~g} / 100 \mathrm{~mL}\left(\mathrm{NH}_{4}\right)_{2} \mathrm{HPO}_{4}\right)(\mathbf{a})$, phosphorus nutrient $(0.1 \mathrm{~g} / 100 \mathrm{~mL}$ phosphorus sources, $1.0 \mathrm{~g} /$ $100 \mathrm{~mL}$ rice bran and $0.1 \mathrm{~g} / 100 \mathrm{~mL}$ urea) (b), and nitrogen nutrient $(0.1 \mathrm{~g} / 100 \mathrm{~mL}$ nitrogen sources, $1.0 \mathrm{~g} / 100 \mathrm{~mL}$ rice bran and $0.1 \mathrm{~g} /$ $\left.100 \mathrm{~mL} \mathrm{~K}_{2} \mathrm{HPO}_{4}\right)(\mathbf{c})$

\subsection{Bio-stimulation effects of rice bran}

Color changes of the fermentation broth from red to pink and then colorless indicated the gradual conversion from aerobic ( $0-1$ st day), facultative ( 2 nd-3rd days) to anaerobic (4-10th days) metabolic stages in the simulated 

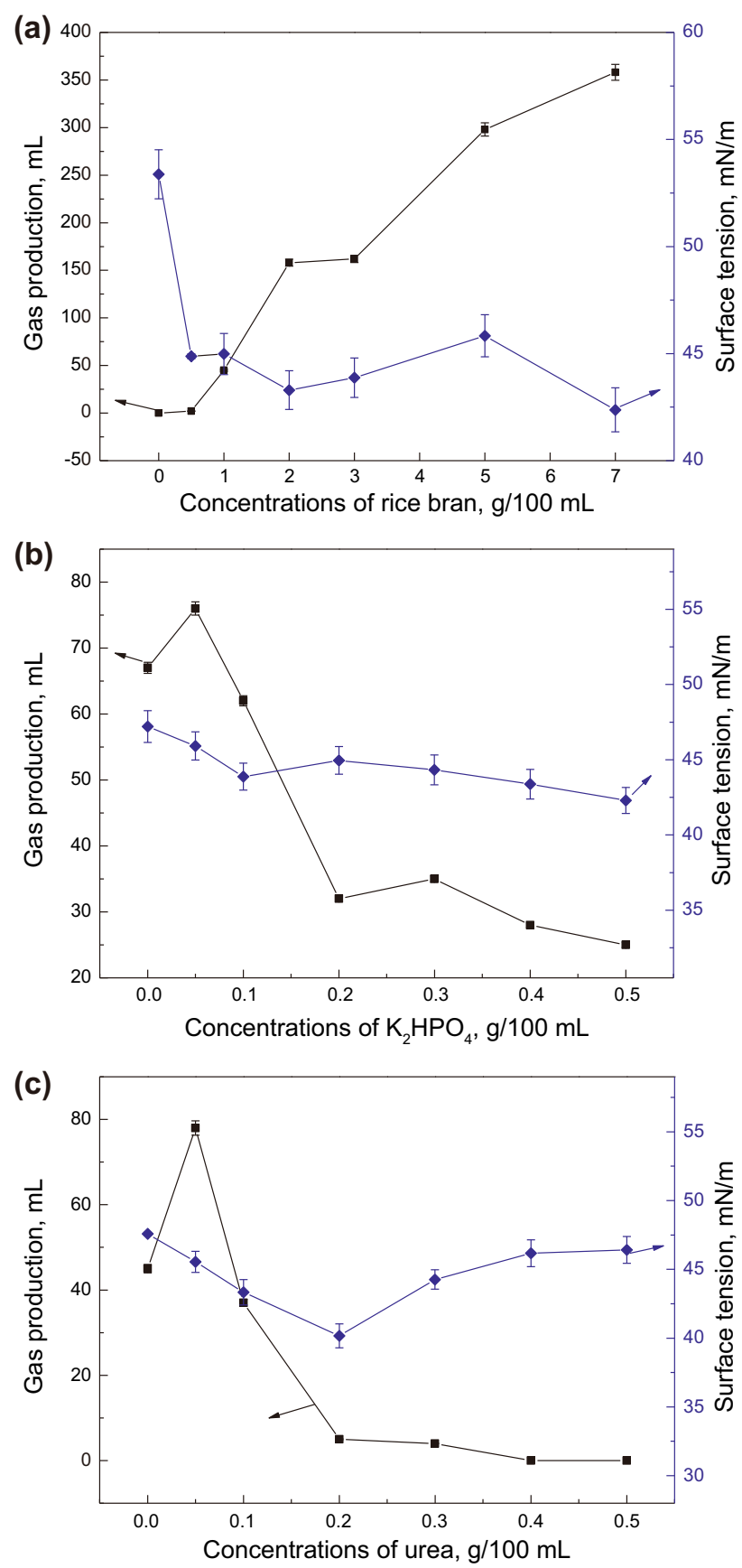

Fig. 2 Preliminary screening of concentrations of rice bran $(0.1 \mathrm{~g} /$ $100 \mathrm{~mL}$ urea and $0.1 \mathrm{~g} / 100 \mathrm{~mL} \mathrm{~K} \mathrm{~K}_{2} \mathrm{HPO}_{4}$, $)(\mathbf{a}), \mathrm{K}_{2} \mathrm{HPO}_{4}(1.0 \mathrm{~g} /$ $100 \mathrm{~mL}$ rice bran and $0.05 \mathrm{~g} / 100 \mathrm{~mL}$ urea) (b), and urea $(1.0 \mathrm{~g} /$ $100 \mathrm{~mL}$ rice bran and $0.1 \mathrm{~g} / 100 \mathrm{~mL} \mathrm{~K} \mathrm{HPO}_{4}$ ) (c)

IMEOR process. The numbers of bacteria rapidly increased from the initial $0.07 \times 10^{9}$ cell $/ \mathrm{mL}$ to $2.4 \times 10^{9}$ cell $/ \mathrm{mL}$ in the aerobic stage and reached a peak value of $4.9 \times 10^{9} \mathrm{cell} / \mathrm{mL}$ in the anaerobic stage (5th day), followed by a slight drop to $4.5 \times 10^{9}$ cell $/ \mathrm{mL}$ at the end of bio-stimulation (Fig. 4a). The $\mathrm{pH}$ values significantly decreased from the initial 7.85 to 5.26 in the facultative stage (3rd day) and then finally decreased to 4.94 (Fig. 4a).
Gas production lasted for 8 days; a total $322 \mathrm{~mL}$ of gases was collected mainly in the facultative stage where the highest gas production rate was observed (Fig. 4b). Gas components varied markedly among stages (Table 3 ). $\mathrm{CO}_{2}$ concentration promptly increased from 0.03 to $42.7 \mathrm{vol} \%$ along with sharp depletion of $\mathrm{O}_{2}$ in the aerobic and facultative stages; $\mathrm{CO}_{2}$ and $\mathrm{H}_{2}$ were the main gases in the anaerobic stage. Surface tension dropped from 62.5 to $37.6 \mathrm{mN} / \mathrm{m}$ in the early anaerobic stage (5th day) when the EI 24 increased rapidly from zero to $61.1 \%$ (Fig. 4c).

\subsection{Microbial community}

There were 17 major bands in the DGGE profiles (Fig. 5a) with obvious variations in the intensities (Fig. 5b), $\mathrm{H}$-index, numbers of bands and microbial abundances among lanes (Table 4). All 17 bands were isolated from the gel, re-amplified, and sequenced. Except for bands 1, 2 and 3, all of the identified genera had sequence similarities of $98 \%$ or higher (Table 5). The phylogenetic tree (Fig. 6) shows that the identified sequences could be divided into three classifications, Proteobacteria, Firmicutes and Acidobacteria. Sequences from bands 3, 4, 5 and 13 were not classified with the phylogenetic tree, which was presumed to be not reported.

\section{Discussion}

\subsection{Optimized bio-stimulation conditions}

Nutrient-rich polysaccharides stimulate indigenous microorganisms in oil reservoirs (Cheng et al. 2010; Feng et al. 2012). Rice bran and wheat bran showed higher emulsification and gas production than the other carbon sources. The market prices of rice bran and wheat bran are similar at approximately $\$ 180$ per ton. Rice bran contained more reducing sugar, total nitrogen and vitamins than wheat bran under previous composition analysis (Wang 2013); therefore, it was identified as a preferred carbon source. Urea and $\mathrm{K}_{2} \mathrm{HPO}_{4}$ contributed largely to the gas production and were determined as the preferred nitrogen and phosphorus nutrients. The concentration of rice bran displayed a positive correlation with gas production, while an excess of rice bran would increase the costs. The concentrations of $\mathrm{K}_{2} \mathrm{HPO}_{4}$ and urea showed negligible influence on bio-stimulation. The concentrations of rice bran, $\mathrm{K}_{2} \mathrm{HPO}_{4}$ and urea at, respectively, 2.00 .05 and $0.05 \mathrm{~g} /$ $100 \mathrm{~mL}$ basically were the balanced nutrient ratios.

The surface tension that directly accounted for oil-flooding effects was selected as the decisive indictor to optimize bio-stimulation conditions. The significance order of nutrient concentrations were rice bran $>$ urea $>\mathrm{K}_{2} \mathrm{HPO}_{4}$ 
Table 1 Experimental results of $3^{3}$ orthogonal designs

\begin{tabular}{llllll}
\hline Runs & $\begin{array}{l}\text { Rice bran, } \\
\mathrm{g} / 100 \mathrm{~mL}\end{array}$ & $\begin{array}{l}\text { Urea, } \\
\mathrm{g} / 100 \mathrm{~mL}\end{array}$ & $\begin{array}{l}\mathrm{K}_{2} \mathrm{HPO}_{4}, \\
\mathrm{~g} / 100 \mathrm{~mL}\end{array}$ & $\begin{array}{l}\text { Gas production, } \\
\mathrm{mL}\end{array}$ & $\begin{array}{l}\text { Surface tension, } \\
\mathrm{mN} / \mathrm{m}\end{array}$ \\
\hline 1 & $1(-1)$ & $0.03(-1)$ & $0.03(-1)$ & 67 & 48.8 \\
2 & 1 & $0.05(0)$ & $0.05(0)$ & 41 & 51.0 \\
3 & 1 & $0.07(+1)$ & $0.07(+1)$ & 61 & 46.5 \\
4 & $2(0)$ & 0.03 & 0.05 & 92 & 46.2 \\
5 & 2 & 0.05 & 0.07 & 64 & 35.4 \\
6 & 2 & 0.07 & 0.03 & 38 & 34.7 \\
7 & $3(+1)$ & 0.03 & 0.07 & 191 & 35.8 \\
8 & 3 & 0.05 & 0.03 & 120 & 39.9 \\
9 & 3 & 0.07 & 0.05 & 125 & 33.9 \\
\hline
\end{tabular}

$(-1)$ for low level, $(0)$ for medium level and $(+1)$ for high level

Table 2 Experimental results of Box-Behnken designs

\begin{tabular}{llllll}
\hline Runs & $\begin{array}{l}\text { Rice bran, } \\
\mathrm{g} / 100 \mathrm{~mL}\end{array}$ & $\begin{array}{l}\text { Urea, } \\
\mathrm{g} / 100 \mathrm{~mL}\end{array}$ & $\begin{array}{l}\mathrm{K}_{2} \mathrm{HPO}_{4}, \\
\mathrm{~g} / 100 \mathrm{~mL}\end{array}$ & $\begin{array}{l}\text { Gas production, } \\
\mathrm{mL}\end{array}$ & $\begin{array}{l}\text { Surface tension, } \\
\mathrm{mN} / \mathrm{m}\end{array}$ \\
\hline 1 & $2(-1)$ & $0.04(-1)$ & $0.07(0)$ & 93 & 48.5 \\
2 & $3(0)$ & $0.07(0)$ & 0.07 & 78 & 38.0 \\
3 & 3 & 0.04 & $0.1(+1)$ & 153 & 46.2 \\
4 & $4(+1)$ & 0.07 & 0.1 & 250 & 41.8 \\
5 & 3 & $0.1(+1)$ & 0.1 & 219 & 42.3 \\
6 & 4 & 0.1 & 0.07 & 310 & 42.6 \\
7 & 2 & 0.07 & 0.1 & 160 & 45.8 \\
8 & 3 & 0.07 & 0.07 & 189 & 40.5 \\
9 & 3 & 0.1 & $0.04(-1)$ & 154 & 41.4 \\
10 & 2 & 0.07 & 0.04 & 100 & 47.8 \\
11 & 2 & 0.1 & 0.07 & 101 & 48.2 \\
12 & 4 & 0.07 & 0.04 & 38 & 44.2 \\
13 & 3 & 0.04 & 0.04 & 85 & 39.1 \\
14 & 3 & 0.07 & 0.07 & 22 & 42.1 \\
15 & 4 & 0.04 & 0.07 & 210 & \\
\hline
\end{tabular}

$(-1)$ for low level, $(0)$ for medium level and $(+1)$ for high level according to the analysis of orthogonal design experiments. By applying response surface regression analysis to the surface tension data from the Box-Behnken experiments, the following second-order equation was established:

$$
\begin{aligned}
Y= & 114.276-22.4558 C-568.595 N-444.793 P \\
& +3.30217 C^{2}+3229.07 N^{2}+2696.85 P^{2} \\
& +6.2500 C N-3.46667 C P+786.667 N P
\end{aligned}
$$

where $Y$ is the surface tension, $\mathrm{mN} / \mathrm{m} ; C, N$ and $P$ are the concentrations $(\mathrm{g} / 100 \mathrm{~mL})$ of rice bran, urea and $\mathrm{K}_{2} \mathrm{HPO}_{4}$, respectively. $C^{2}, N^{2}, C$, and $N$ show significant influences on surface tension with $P$ values of $0.028,0.043$ and 0.029 , respectively. ANOVA results indicated a good consistency between experimental and predicted values with a $P$ value of 0.017 and a $R^{2}$ value of 0.902 . The experimental surface tension $(40.6 \mathrm{mN} / \mathrm{m})$ under the optimized bio-stimulation conditions agreed well with the predicted value, which the predicted minimum surface tension $(38.6 \mathrm{mN} / \mathrm{m})$ was also obtained under the optimal bio-stimulation conditions.

\subsection{Bio-stimulation effects of rice bran for promoting IMEOR}

Indigenous microorganisms became active and reached a logarithmic growth phase shortly after addition of rice bran supplemented with urea and $\mathrm{K}_{2} \mathrm{HPO}_{4}$. A stationary growth phase appeared in the later anaerobic stage due to depletion of nutrients. Acids were rapidly produced in the aerobic and facultative stages, and their production and utilization reached an approximate balance in the anaerobic stage. Acid production favors flooding, whereas a lower $\mathrm{pH}$ value is harmful to some indigenous microorganism species.

Gas-producing bacteria were sensitive to rice bran, and gas production mainly occurred in the aerobic and facultative stages. As $\mathrm{O}_{2}$ was consumed, $\mathrm{CO}_{2}$ was generated 

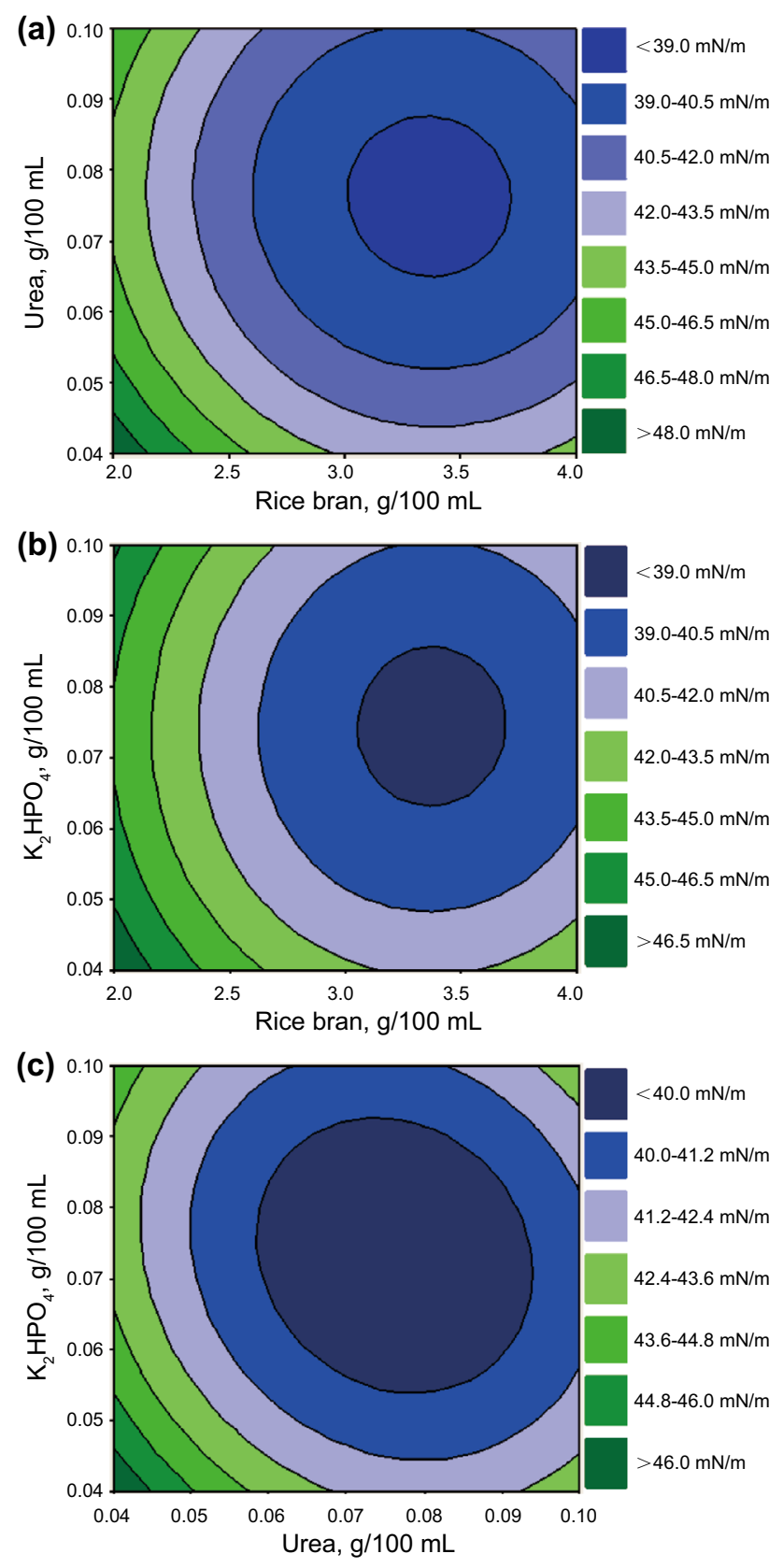

Fig. 3 Interaction effects of rice bran and urea with $\mathrm{K}_{2} \mathrm{HPO}_{4}$ concentration of $0.07 \mathrm{~g} / 100 \mathrm{~mL}$ (a), rice bran and $\mathrm{K}_{2} \mathrm{HPO}_{4}$ with urea concentration of $0.07 \mathrm{~g} / 100 \mathrm{~mL}(\mathbf{b})$, and urea and $\mathrm{K}_{2} \mathrm{HPO}_{4}$ with rice bran at a concentration of $3.0 \mathrm{~g} / 100 \mathrm{~mL}$ (c) on surface tension

rapidly with the growth of aerobic bacteria. The emergence of $\mathrm{H}_{2}$ signified that anaerobic bacteria became active, while aerobic bacteria were inhibited in the anaerobic stage. Injecting an extra amount of air or $\mathrm{O}_{2}$ can extend the aerobic and facultative stages, and contribute to re-pressurization and $\mathrm{CO}_{2}$ flooding.

Aerobic bacteria rapidly produce emulsifiers utilizing sufficient nutrients and $\mathrm{O}_{2}$ in the aerobic stage. After that, facultative and anaerobic bacteria became dominant and
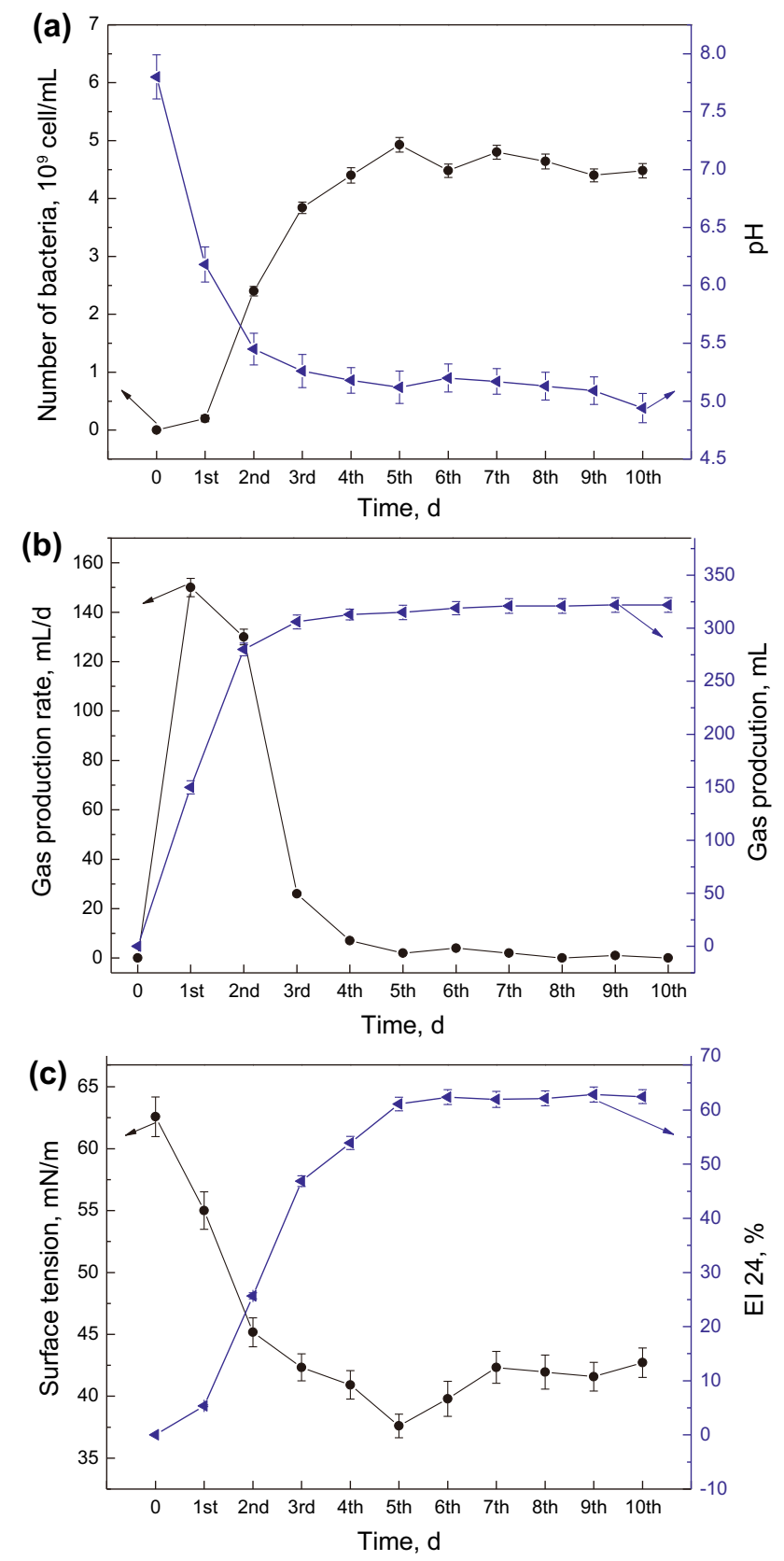

Fig. $4 \mathrm{pH}$ values and numbers of bacteria (a), gas production and production rate (b), surface tension and EI 24 (c) of fermentation broth in a simulated IMEOR process

emulsifier production decreased; therefore, no further significant decrease of surface tension was observed. The EI 24 demonstrated the high emulsification of crude oil at the end of bio-stimulation. Emulsifiers play a critical role in MEOR processes. Continuous supply of nutrients and $\mathrm{O}_{2}$ to an oil reservoir would contribute to the production of a greater amount of emulsifiers.

The rice bran, as a carbon nutrient stimulator, successfully stimulated beneficial indigenous microorganisms and 
Table 3 Composition of produced gases at different days during a simulated IMEOR process

\begin{tabular}{|c|c|c|c|c|c|c|c|c|c|c|}
\hline \multirow[t]{2}{*}{ Components } & \multicolumn{2}{|l|}{0 day } & \multicolumn{2}{|c|}{ 2nd day } & \multicolumn{2}{|c|}{ 3rd day } & \multicolumn{2}{|c|}{ 8th day } & \multicolumn{2}{|c|}{ 10th day } \\
\hline & vol\% & $\mathrm{mL}$ & vol\% & $\mathrm{mL}$ & vol\% & $\mathrm{mL}$ & vol\% & $\mathrm{mL}$ & vol\% & $\mathrm{mL}$ \\
\hline $\mathrm{N}_{2}$ & 78 & 117 & 39.5 & 118.5 & 33.9 & 101.7 & 0 & 0 & 0 & 0 \\
\hline $\mathrm{O}_{2}$ & 21 & 31.5 & 2.3 & 6.9 & 1.9 & 5.7 & 0 & 0 & 0 & 0 \\
\hline $\mathrm{H}_{2}$ & 0 & 0 & 12.8 & 38.4 & 30.7 & 92.1 & 6.3 & 18.9 & 20.4 & 61.2 \\
\hline $\mathrm{CO}_{2}$ & 0.03 & 0.05 & 42.7 & 128.1 & 32.1 & 96.3 & 89.8 & 269.4 & 76.1 & 228.3 \\
\hline Others $\left(\mathrm{C}_{2} \mathrm{H}_{6}, \mathrm{C}_{3} \mathrm{H}_{8}\right.$, etc. $)$ & 0.97 & 0.15 & 2.7 & 8.1 & 1.4 & 4.2 & 3.9 & 11.7 & 3.5 & 10.5 \\
\hline
\end{tabular}

(a)

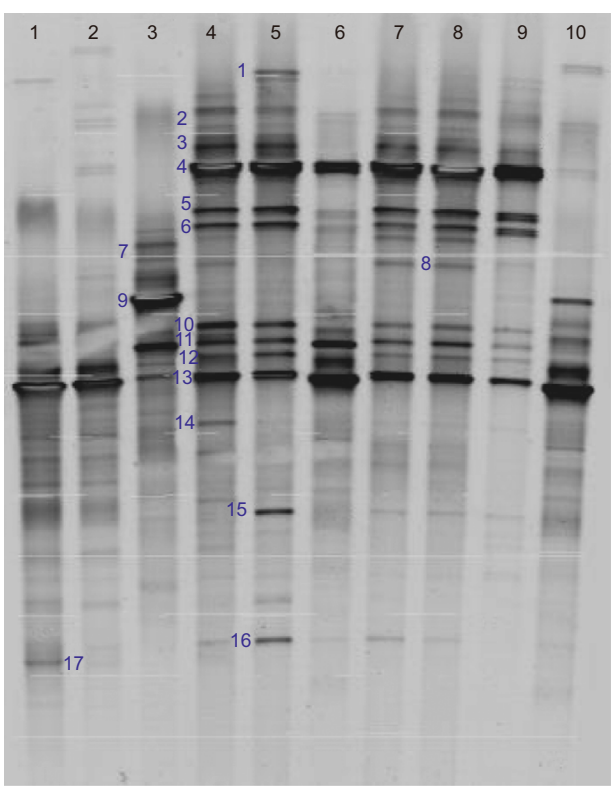

Fig. 5 DGGE profile of bacterial samples from different days (a), schematic diagram of relative band intensities in DGGE profiles (b). Note Lane number represented the bacterial samples collected in (b)

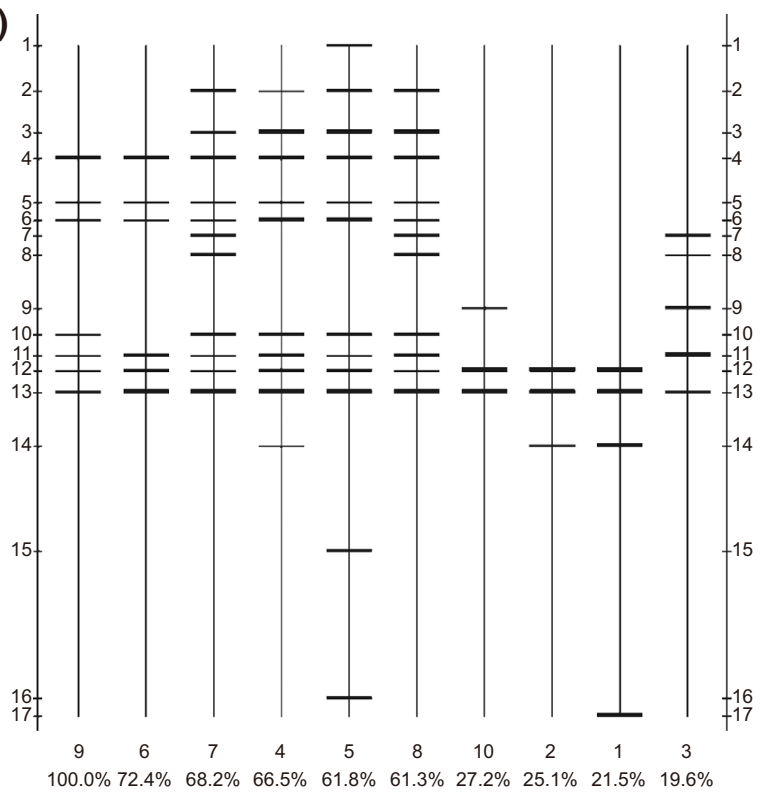

different days. Lane 1-the 1st day; Lane 2-the 2nd day; and so on; Lane 10-the 10th day
Table 4 Diversity index $(H)$, numbers of bands and abundances of DGGE profiles

\begin{tabular}{lllllllllll}
\hline Lane no. & 1 & 2 & 3 & 4 & 5 & 6 & 7 & 8 & 9 & 10 \\
\hline$H$-index & 2.45 & 2.40 & 2.05 & 2.77 & 2.61 & 1.93 & 2.61 & 2.43 & 1.98 & 1.99 \\
Numbers of bands & 12 & 14 & 8 & 21 & 15 & 9 & 14 & 13 & 10 & 10 \\
Microbial abundance & 1665 & 157 & 1150 & 476 & 368 & 282 & 1908 & 358 & 239 & 226 \\
\hline
\end{tabular}

enhanced the production of acids, gases and emulsifiers, and hence effectively promoted the IMEOR process.

\subsection{Diversity and functions analysis of microbial community}

Changes in microbial community structure occurred in the simulated IMEOR process (Table 6). Microbial diversity $(H$-index $)$ was significant on the 1 st, 4 th, 5 th and 7 th days and microbial abundance peaked markedly on the $1 \mathrm{st}$, $3 \mathrm{rd}$ and 7th days. Clostridium sp., Acidobacteria sp., Pseudomonas sp. and Bacillus sp. were the dominant bacteria. Of these bacteria, Bacillus sp. and Pseudomonas sp. dominated the aerobic stage and Acidobacteria sp. dominated the facultative and anaerobic stages. Clostridium sp. was highly distributed throughout the simulated IMEOR process.

Aerobic bacteria were stimulated and caused a higher microbial diversity and abundance in the aerobic stage (1st day). Clostridium sp., uncultured Acidobacteria bacterium, 
Table 5 Comparisons of nucleotide sequences of sequenced DGGE bands

\begin{tabular}{|c|c|c|c|}
\hline Band no. & Closest relatives & Accession No. & Identity, \% \\
\hline \multirow[t]{2}{*}{1} & Clostridium sp. & HM801879.1 & 95 \\
\hline & Uncultured Clostridium sp. & JX273758.1 & 95 \\
\hline \multirow[t]{2}{*}{2} & Clostridium sulfidigenes strain & HM163534.1 & 96 \\
\hline & Uncultured Enterococcus sp. & DQ232854.1 & 96 \\
\hline \multirow[t]{2}{*}{3} & Achromobacter sp. & AB772984.1 & 96 \\
\hline & Uncultured bacterium clone & KC465632.1 & 97 \\
\hline \multirow[t]{2}{*}{4} & Bacillus cereus strain & КC683782.1 & 98 \\
\hline & Uncultured bacterium clone & GU002857.1 & 98 \\
\hline \multirow[t]{2}{*}{5} & Pseudomonas aeruginosa strain & KC570343.1 & 100 \\
\hline & Uncultured Pseudomonas sp. & KC470004.1 & 100 \\
\hline \multirow[t]{2}{*}{6} & Clostridium indolis strain & JX960755.1 & 100 \\
\hline & Uncultured bacterium clone & КC000040.1 & 100 \\
\hline \multirow[t]{2}{*}{7} & Brevundimonas sp. & HF571531.1 & 99 \\
\hline & Uncultured Brevundimonas sp. clone & JQ701321.1 & 99 \\
\hline \multirow[t]{2}{*}{8} & Pantoea agglomerans strain & КC009691.1 & 100 \\
\hline & Uncultured bacterium clone & KC299005.1 & 100 \\
\hline \multirow[t]{2}{*}{9} & Ochrobactrum sp. & KC493414.1 & 100 \\
\hline & Uncultured Ochrobactrum sp. & KC502956.1 & 100 \\
\hline \multirow[t]{2}{*}{10} & Arcobacter sp. & FN397894.1 & 99 \\
\hline & Uncultured Arcobacter sp. & HM245616.1 & 99 \\
\hline \multirow[t]{2}{*}{11} & Agrobacterium vitis strain & KC196472.1 & 99 \\
\hline & Uncultured bacterium clone & JX872344.1 & 99 \\
\hline 12 & Uncultured Acidobacteria bacterium clone & DQ829628.1 & 99 \\
\hline \multirow[t]{2}{*}{13} & Clostridium sp. & KC331196.1 & 100 \\
\hline & Uncultured Clostridium sp. & KC110473.1 & 100 \\
\hline \multirow[t]{2}{*}{14} & Bacillus aerius strain & KC469617.1 & 100 \\
\hline & Uncultured bacterium clone & KC414651.1 & 100 \\
\hline \multirow[t]{2}{*}{15} & Sulfurospirillum carboxydovorans strain & AY740528.1 & 99 \\
\hline & Uncultured epsilon proteobacterium & AJ576003.1 & 99 \\
\hline \multirow[t]{2}{*}{16} & Paenibacillus sp. & KC134361.1 & 99 \\
\hline & Uncultured bacterium clone & JX223186.1 & 99 \\
\hline \multirow[t]{2}{*}{17} & Pseudomonas sp. & KC433644.1 & 100 \\
\hline & Uncultured Pseudomonas sp. clone & КC253432.1 & 100 \\
\hline
\end{tabular}

Bacillus aerius, and Pseudomonas sp. were stimulated and resulted in the increase of bacteria numbers. B. aerius and Pseudomonas sp. began to produce acids and emulsifiers (e.g., biosurfactants) by utilizing $\mathrm{O}_{2}$, nutrients and even crude oil (Abdel-Mawgoud et al. 2009; Banat 1995), then both $\mathrm{pH}$ and surface tension decreased.

Aerobic bacteria (e.g., Pseudomonas sp.) were gradually inhibited with consumption of $\mathrm{O}_{2}$, and facultative bacteria became dominant in the facultative stage. Microbial abundance rebounded in the 3rd day, while the genera of bacteria were not rich. Clostridium sp. began to produce gases by utilizing nutrients (Taguchi et al. 1996). Brevundimonas sp., Pantoea agglomerans, Ochrobactrum sp., and Agrobacterium vitis were stimulated. Among these, Brevundimonas sp. and Ochrobactrum sp. can decompose crude oil to produce biosurfactants and acids (Arulazhagan and Vasudevan 2011; Ghosal et al. 2010; Ruggeri et al. 2009; Takahashi et al. 1999); Agrobacterium vitis can promote the metabolism of petroleum-degrading bacteria (Chalneau et al. 1995). The functions of P. agglomerans in an IMEOR process have not been reported. The co-effects of microbial community increased the bacteria numbers and EI 24, but decreased both the $\mathrm{pH}$ and surface tension.

As anaerobic bacteria were stimulated in the anaerobic stage, the number of bacterial genera significantly increased on the 4th day and the microbial diversity reached its maximum level. Clostridium sp., Clostridium sulfidigenes, Clostridium indolis, Achromobacter sp., Bacillus cereus, B. aerius, Pseudomonas aeruginosa, Arcobacter sp., A. vitis, uncultured Acidobacteria bacteria 


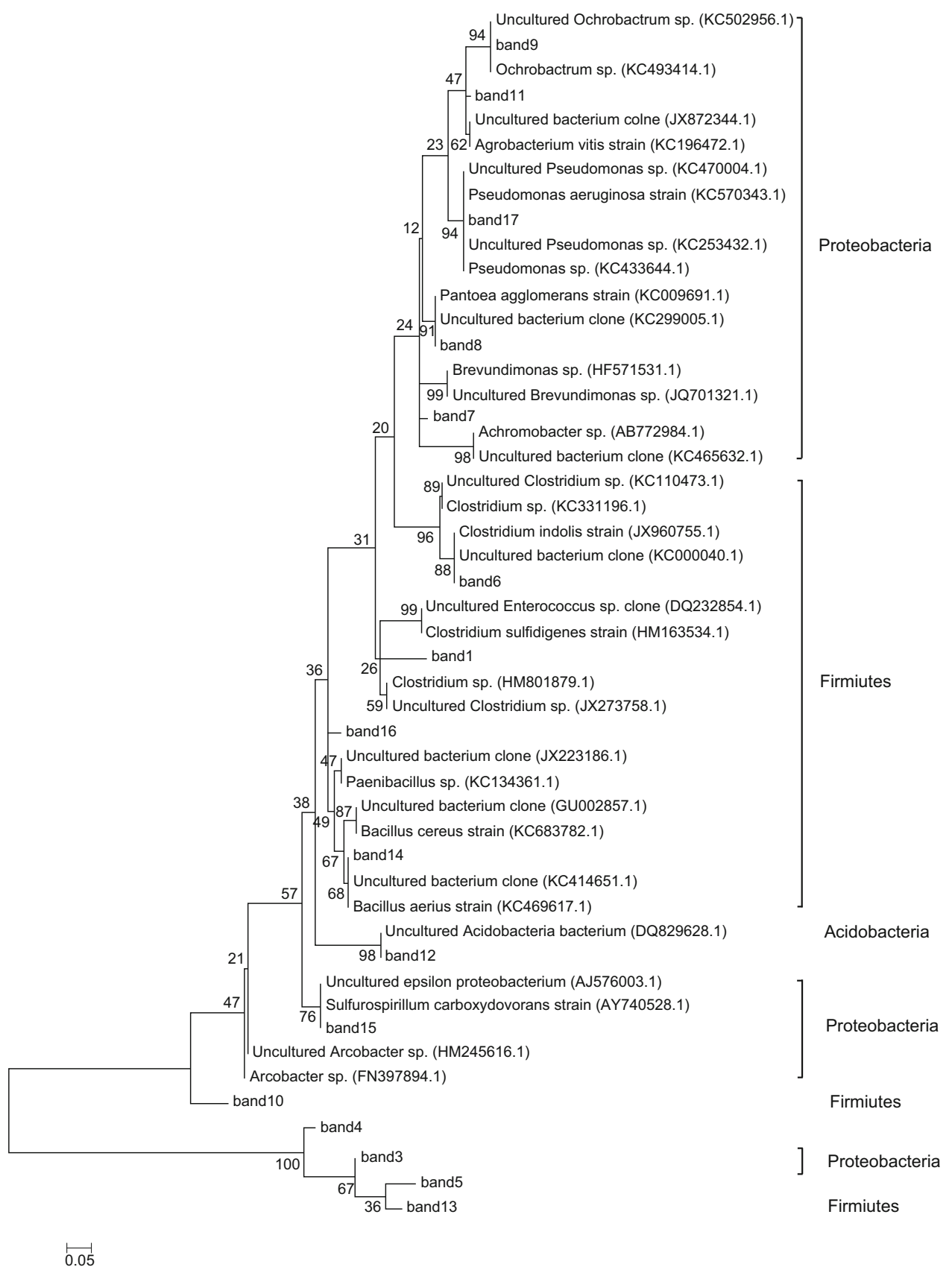

Fig. 6 Phylogenetic tree of 16S rDNA sequences from DGGE profiles

and the other uncultured bacteria co-built up the most complex structure of microbial community. B. cereus can produce acids but not gases in anaerobic conditions (Nazina et al. 2003). P. aeruginosa can produce biosurfactants by degrading crude oil (Das and Mukherjee 2007). Sulfurospirillum carboxydovorans and Paenibacillus sp. appeared on the 5th day. The former can inhibit sulfatereducing bacteria (Hubert and Voordouw 2007), and the latter may produce biopolymers (Wang et al. 2008a, b). The bacteria abundance reached a peak value and surface tension at a minimum on the 5th day when the $\mathrm{pH}$ and EI 24 almost attained their lowest and highest values, respectively; meanwhile, the gas production declined significantly. The number of bacterial genera decreased, but the microbial abundance increased, and B. cereus, A. vitis, uncultured Acidobacteria and Clostridium sp. became dominant on the 6th day. As anaerobic bacteria becoming adapted, microbial abundance recovered again and reached its peak value on the 7th day when the microbial diversity remained high. After that, microbial diversity and 
Table 6 Dominant bacteria and the community succession during a simulated IMEOR process

\begin{tabular}{|c|c|c|c|c|c|c|c|c|c|c|c|}
\hline \multirow[t]{2}{*}{ Band no. } & \multirow[t]{2}{*}{ Genus } & \multicolumn{10}{|c|}{ Dominance during a simulated IMEOR process } \\
\hline & & $\begin{array}{l}1 \text { st } \\
\text { day }\end{array}$ & $\begin{array}{l}\text { 2nd } \\
\text { day }\end{array}$ & $\begin{array}{l}\text { 3rd } \\
\text { day }\end{array}$ & $\begin{array}{l}\text { 4th } \\
\text { day }\end{array}$ & $\begin{array}{l}\text { 5th } \\
\text { day }\end{array}$ & $\begin{array}{l}\text { 6th } \\
\text { day }\end{array}$ & $\begin{array}{l}\text { 7th } \\
\text { day }\end{array}$ & $\begin{array}{l}\text { 8th } \\
\text { day }\end{array}$ & $\begin{array}{l}\text { 9th } \\
\text { day }\end{array}$ & $\begin{array}{l}\text { 10th } \\
\text { day }\end{array}$ \\
\hline 1 & $\begin{array}{l}\text { Clostridium sp. } \\
\text { Uncultured Clostridium sp. }\end{array}$ & - & - & - & - & + & - & - & - & - & - \\
\hline 2 & $\begin{array}{l}\text { Clostridium sulfidigenes strain } \\
\text { Uncultured Enterococcus sp. }\end{array}$ & - & - & - & + & + & - & + & + & - & - \\
\hline 3 & $\begin{array}{l}\text { Achromobacter sp. } \\
\text { Uncultured bacterium clone }\end{array}$ & - & - & - & + & + & - & + & + & - & - \\
\hline 4 & $\begin{array}{l}\text { Bacillus cereus strain } \\
\text { Uncultured bacterium clone }\end{array}$ & - & - & - & + & + & + & + & + & + & - \\
\hline 5 & $\begin{array}{l}\text { Pseudomonas aeruginosa strain } \\
\text { Uncultured Pseudomonas sp. }\end{array}$ & - & - & - & + & + & + & + & + & + & - \\
\hline 6 & $\begin{array}{l}\text { Clostridium indolis strain } \\
\text { Uncultured bacterium clone }\end{array}$ & - & - & - & + & + & + & + & + & + & - \\
\hline 7 & $\begin{array}{l}\text { Brevundimonas sp. } \\
\text { Uncultured Brevundimonas sp. Clone }\end{array}$ & - & - & + & - & - & - & + & + & - & - \\
\hline 8 & $\begin{array}{l}\text { Pantoea agglomerans strain } \\
\text { Uncultured bacterium clone }\end{array}$ & - & - & + & - & - & - & + & + & - & - \\
\hline 9 & $\begin{array}{l}\text { Ochrobactrum sp. } \\
\text { Uncultured Ochrobactrum sp. }\end{array}$ & - & - & + & - & - & - & - & - & - & + \\
\hline 10 & $\begin{array}{l}\text { Arcobacter sp. } \\
\text { Uncultured Arcobacter sp. }\end{array}$ & - & - & - & + & + & - & + & + & + & - \\
\hline 11 & $\begin{array}{l}\text { Agrobacterium vitis strain } \\
\text { Uncultured bacterium clone }\end{array}$ & - & - & + & + & + & + & + & + & + & - \\
\hline 12 & Uncultured Acidobacteria bacterium clone & + & + & - & + & + & + & + & + & + & + \\
\hline 13 & $\begin{array}{l}\text { Clostridium sp. } \\
\text { Uncultured Clostridium sp. }\end{array}$ & + & + & + & + & + & + & + & + & + & + \\
\hline 14 & $\begin{array}{l}\text { Bacillus aerius strain } \\
\text { Uncultured bacterium clone }\end{array}$ & + & + & - & + & - & - & - & - & - & - \\
\hline 15 & $\begin{array}{l}\text { Sulfurospirillum carboxydovorans strain } \\
\text { Uncultured epsilon proteobacterium }\end{array}$ & - & - & - & - & + & - & - & - & - & - \\
\hline 16 & $\begin{array}{l}\text { Paenibacillus sp. } \\
\text { Uncultured bacterium clone }\end{array}$ & - & - & - & - & + & - & - & - & - & - \\
\hline 17 & $\begin{array}{l}\text { Pseudomonas sp. } \\
\text { Uncultured Pseudomonas sp. Clone }\end{array}$ & + & - & - & - & - & - & - & - & - & - \\
\hline
\end{tabular}

$(+)$ represent the dominant bacteria, $(-)$ represent the non-dominant bacteria or absence

abundance both reduced to their minimum values at the end of bio-stimulation with the depletion of nutrients.

The structure and relative abundance of the microbial community, especially the interactions between different microorganisms, have great influence on promoting IMEOR. Rice bran, with the participation of the other preferred nutrients, could enhance the microbial diversity as well as strengthen the multiple functions of producing gases, acids and emulsifiers. The results indicated that rice bran can effectively promote IMEOR.

\section{Conclusion}

The potential of rice bran as a carbon nutrient for promoting IMEOR was investigated. Rice bran showed great bio-stimulation effects on producing gases, acids and emulsifiers with the supplements of $\mathrm{K}_{2} \mathrm{HPO}_{4}$ and urea. The oil reservoirs were re-pressurized and $\mathrm{pH}$ and surface tension decreased, which contributed to the IMEOR process. The indigenous microbial community showed remarkable successions, and the beneficial functioning 
bacteria were stimulated in the simulated IMEOR process. Clostridium sp., Acidobacteria sp., Bacillus sp., and Pseudomonas sp. dominated the IMEOR process. Microbial activities and interactions among indigenous microorganisms enhanced the IMEOR process. The results indicated the potential of rice bran for promoting IMEOR due to its effectiveness and low cost.

Acknowledgments This project was supported in part by the National Natural Science Foundation of China (Nos. 51209216 and 21306229) and the Korean RDA Grant (No. PJ009472). C. Chen was a China Scholarship Council scholarship recipient.

Open Access This article is distributed under the terms of the Creative Commons Attribution 4.0 International License (http://crea tivecommons.org/licenses/by/4.0/), which permits unrestricted use, distribution, and reproduction in any medium, provided you give appropriate credit to the original author(s) and the source, provide a link to the Creative Commons license, and indicate if changes were made.

\section{References}

Abdel-Mawgoud AM, Aboulwafa MM, Hassouna NAH. Characterization of rhamnolipid produced by Pseudomonas aeruginosa isolate Bs20. Appl Biochem Biotechnol. 2009;157(2):329-45.

Andreoni V, Gavalca L, Rao MA. Bacteria communities and enzyme activities of PAHs polluted soils. Chemosphere. 2004;57:401-12.

Arulazhagan P, Vasudevan N. Biodegradation of polycyclic aromatic hydrocarbons by a halotolerant bacterial strain Ochrobactrum sp. VA1. Mar Pollut Bull. 2011;62(2):388-94.

Banat IM. Biosurfactants production and possible uses in microbial enhanced oil recovery and oil pollution remediation: a review. Bioresour Technol. 1995;51(1):1-12.

Banat IM, Franzetti A, Gandolfi I, et al. Microbial biosurfactants production, applications and future potential. Appl Microbiol Biotechnol. 2010;87(2):427-44.

Bao M, Kong X, Jiang G, Wang X, Li X. Laboratory study on activating indigenous microorganisms to enhance oil recovery in Shengli Oilfield. J Pet Sci Eng. 2009;66(1-2):42-6.

Brown LR. Microbial enhanced oil recovery (MEOR). Curr Opin Microbiol. 2010;13(3):316-20.

Castoren-Cortés G, Zapata-Peñasco I, Roldán-Carrillo $\mathrm{T}$, et al. Evaluation of indigenous anaerobic microorganisms from Mexican carbonate reservoirs with potential MEOR application. J Pet Sci Eng. 2012;81:86-93.

Chalneau CH, Morel JL, Oudot J. Microbial degradation in soil microcosms of fuel oil hydrocarbons from drilling cuttings. Environ Sci Technol. 1995;29(6):1615-21.

Chen X, Wang J, Li D. Optimization of solid-state medium for the production of inulinase by Kluyveromyces S120 using response surface methodology. Biochem Eng J. 2007;34(2):179-84.

Chen JL, Au KC, Wong YS, et al. Using orthogonal design to determine optimal conditions for biodegradation of phenanthrene in mangrove sediment slurry. J Hazard Mater. 2010;176(1-3):666-71.

Cheng H, Liu M, Hu J, et al. Study on novel nutrient system based on starch-cellulose for microbial flooding. Acta Pet Sin. 2010;31(1): 105-9 (in Chinese).

da Silva MLB, Soares HM, Furigo A Jr, et al. Effects of nitrate injection on microbial enhanced oil recovery and oilfield reservoir souring. Appl Biochem Biotechnol. 2014;174(5):1810-21.
Das K, Mukherjee AK. Crude petroleum-oil biodegradation efficiency of Bacillus subtilis and Pseudomonas aeruginosa strains isolated from a petroleum-oil contaminated soil from North-East India. Bioresour Technol. 2007;98(7):1339-45.

Dastgheib SM, Amoozegar MA, Elahi E, Asad S, Banat IM. Bioemulsifier production by a halothermophilic Bacillus strain with potential applications in microbially enhanced oil recovery. Biotechnol Lett. 2008;30(2):263-70.

Feng Q-X, Ma X-P, Cheng H-Y, et al. Application of a novel amylum-cellulose nutrient system for microbial flooding in Dagang oilfield, China. In: SPE improved oil recovery symposium, Vol. 1. Tulsa: Society of Petroleum Engineers; 2012. p. 25-34.

Fuhrman JA. Microbial community structure and its functional implications. Nature. 2009;459(7244):193-9.

Gao CH, Zerki A. Applications of microbial-enhanced oil recovery technology in the past decade. Energy Sour Part A. 2011;33(10): 972-89.

Gao P, Li G, Dai X, et al. Nutrients and oxygen alter reservoir biochemical characters and enhance oil recovery during biostimulation. World J Microbiol Biotechnol. 2013;29(11):2045-54.

Ghosal D, Chakraborty J, Khara P, et al. Degradation of phenanthrene via meta-cleavage of 2-hydroxy-1-naphthoic acid by Ochrobactrum sp. strain PWTJD. FEMS Microbiol Lett. 2010;313(2):103-10.

Hubert C, Voordouw G. Oil field souring control by nitrate-reducing Sulfurospirillum spp. that outcompete sulfate-reducing bacteria for organic electron donors. Appl Environ Microbiol. 2007;73(8): 2644-52.

Ji G, Liao B, Tao H, et al. Analysis of bacteria communities in an upflow fixed-bed (UFB) bioreactor for treating sulfide in hydrocarbon wastewater. Bioresour Technol. 2009;100:5056-62.

Joshi S, Bharucha C, Jha S, et al. Biosurfactant production using molasses and whey under thermophilic conditions. Bioresour Technol. 2008;99(1):195-9.

Kitamoto D, Morita T, Fukuoka T. Self-assembling properties of glycolipid biosurfactants and their potential applications. Curr Opin Colloid Interface Sci. 2009;14(5):315-28.

Kobayashi H, Kawaguchi H, Endo K, et al. Analysis of methane production by microorganisms indigenous to a depleted oil reservoir for application in microbial enhanced oil recovery. J Biosci Bioeng. 2012;113(1):84-7.

Lazar I, Petrisor IG, Yen TF. Microbial enhanced oil recovery (MEOR). Pet Sci Technol. 2007;25(11):1353-66.

Nazina TN, Sokolova DS, Grigoryan AA, et al. Production of oilreleasing compounds by microorganisms from the Daqing Oil Field, China. Microbiology. 2003;72(2):173-8.

$\mathrm{Ng}$ IS, Li CW, Chan SP, et al. High-level production of a thermoacidophilic $\beta$-glucosidase from Penicillium citrinum YS40-5 by solid-state fermentation with rice bran. Bioresour Technol. 2010;101(4):1310-7.

Noike T, Mizuno O. Hydrogen fermentation of organic municipal wastes. Water Sci Technol. 2000;42(12):155-62.

Reddy MS, Naresh B, Leela T, et al. Biodegradation of phenanthrene with biosurfactant production by a new strain of Brevibacillus sp. Bioresour Technol. 2010;101(20):7980-3.

Ruggeri C, Franzetti A, Bestetti G, et al. Isolation and characterisation of surface active compound-producing bacteria from hydrocarbon-contaminated environments. Int Biodeterior Biodegrad. 2009;63(7):936-42.

Sarafzadeh P, Hezave AZ, Ravanbakhsh M, et al. Enterobacter cloacae as biosurfactant producing bacterium: differentiating its effects on interfacial tension and wettability alteration mechanisms for oil recovery during MEOR process. Colloid Surface B. 2013;105(1):223-9.

Sen R. Biotechnology in petroleum recovery: the microbial EOR. Prog Energy Combust. 2008;34(6):714-24. 
She YH, Zhang F, Xia JJ, et al. Investigation of biosurfactantproducing indigenous microorganisms that enhance residue oil recovery in an oil reservoir after polymer flooding. Appl Microbiol Biotechnol. 2011;163(2):223-34.

Spirov P, Ivanova Y, Rudyk S. Modelling of microbial enhanced oil recovery application using anaerobic gas-producing bacteria. Pet Sci. 2014;11(2):272-8.

Taguchi F, Yamada K, Hasegawa K, et al. Continuous hydrogen production by Clostridium sp. strain no. 2 from cellulose hydrolysate in an aqueous two-phase system. J Ferment Bioeng. 1996;82:80-3.

Takahashi R, Yamayoshi K, Fujimoto N, et al. Production of $(S, S)$ ethylenediamine- $N, N$-disuccinic acid from ethylenediamine and fumaric acid by bacteria. Biosci Biotechnol Biochem. 1999;63(7):1269-73.

Tanaka T, Hoshina M, Tanabe S, et al. Production of d-lactic acid from defatted rice bran by simultaneous saccharification and fermentation. Bioresour Technol. 2006;97(2):211-7.

Tang YQ, Li Y, Zhao JY, et al. Microbial communities in long-term, water flooded petroleum reservoirs with different in situ temperatures in the Huabei Oilfield, China. PLoS One. 2012;7(3):e33535.

Wang J. Study of activator screening and its impact on indigenous microbial communities in the Xinjiang Oilfield. Master Dissertation. China University of Petroleum, Beijing. 2013. p. 26-28 (in Chinese).
Wang J, Ma T, Zhao L, et al. Monitoring exogenous and indigenous bacteria by PCR-DGGE technology during the process of microbial enhanced oil recovery. J Ind Microbiol Biotechnol. 2008a;35(6):619-28.

Wang J, Yan G, An M, et al. Study of a plugging microbial consortium using crude oil as sole carbon source. Pet Sci. 2008b;5(4):367-74.

Wang X, Li D, Hendry P, et al. Effect of nutrient addition on an oil reservoir microbial population: implications for enhanced oil recovery. J Pet Environ Biotechnol. 2012;3(2):118.

Yao C, Lei G, Ma J, et al. Laboratory experiment, modeling and field application of indigenous microbial flooding. J Pet Sci Eng. 2012;90-91:39-47.

Zhang F, She YH, Ma SS, et al. Response of microbial community structure to microbial plugging in a mesothermic petroleum reservoir in China. Appl Microbiol Biotechnol. 2010;88(6):1413-22.

Zhang F, She YH, Li HM, et al. Impact of an indigenous microbial enhanced oil recovery field trial on microbial community structure in a high pour-point oil reservoir. Appl Microbiol Biotechnol. 2012;95(3):811-21.

Zhou QY, Wang SF. Microbiology of environmental engineering. Beijing: Higher Education Press; 2004. p. 292-3 (in Chinese). 